\title{
「窒素酸化物防除技術の現状々今後」の 特集にあたつて
}

\author{
大阪工業大学教授, 本会世話人新良宏一郎
}

昭和 48 年 5 月 $\mathrm{NO}_{2}$ 亿係る環境基準が設定され，その達成期間は地域の状況 により 5 年あるいは 8 年を目標とするととが発表された. つづいて昭和 48 年 8 月に NOx の排出基準が設定された。

ての排出基準は今迄に開発されている燃焼方法の改善などによって達成が可 能な程度のあのであったが, 一方, 環境基準はきわめて厳しいあのであって, 排出基準を守るだけでは十分でなく，移動発生源，固定発生源の両方にわた り，大幅な排出量の削減を図らなくては，到底達成ができないものである.

したがって, 以来, 脱硝技術の開発研究が各方面にわたり熱心淮められて きた。

その結果, 着々とその成果が収められているが, なお, 現段階では, 固定発 生源での実用性は可成むつかしいという感じが強い.

現在，脱硫は湿式の石灰・石膏法が多く実施されているが，脱硝については 湿式法より李乾式法がより多く研究されており，とくにアンモニア還元法が多 い.との方法はクリーン排ガスについては技術的にはすでに問題のない段階に 達しているといわ机る.

しかし，一般燃焼排ガスについては，なお，ばいじんによる触媒の閉塞， $\mathrm{SO}_{2}$ による妨害などの問題がある.

湿式法は廃水の二次処理の問題があるが，脱硫，脱硝が同時に行える可能性 があり，湿式還元法においては，新しい触媒，および還元剂の開発など今後の 研究に期待できるところあ多く楽しみである.

いずれにしても現段階では, 乾式, 湿式已む大規模の実用化についての種々 の問題点が明らかにされたところであり，今後研究解決すべきものが多いよう である。

現在の脱硝装置の費用は，規模にもよるが，重油 $1 \mathrm{k} l$ 当り建設費は約 1 億 円，処理費は約 1 万円を要するといわれているが，今後の実用化にはさらに一 層の経済性の向上が図られねばならない.

中小規模発生施設については，脱硝に代わるに，燃料の転換と低 NOx 燃焼 法の採用がより適当かむ知れない。

本特集は，乙のような現段階において，関係諸権威にお願いして NOx 防除 技術についての今日までの研究を総括し, 将来の展望を述べて頂くこととし た. 今後の研究推進に役立てて頂きたい。こてに，脱硝技術の早期完成を心か ら祈ります。 